\title{
IMAGINED COMMUNITY, IMAGINED IDENTITY, AND INVESTMENT IN LANGUAGE LEARNING: AN AUTOETHNOGRAPHICAL ACCOUNT
}

\author{
Nguyen Xuan Nghia* \\ School of Foreign Languages, Hanoi University of Science and Technology \\ 1 Dai Co Viet Road, Ha Noi, Viet Nam \\ Received 14 February 2020 \\ Revised 13 April 2020; Accepted 29 May 2020
}

\begin{abstract}
Language learning, viewed through post-structuralist prism, is not the practice of the individual per se but a social practice characterized by the multiple and changing learner identity in direct contact with inequitable power relations (Norton, 2013). Not always does it deal with the immediate identity of the learner in the real-time setting, but also identities defined through "the power of the imagination" in "not immediately accessible and tangible" communities (Norton, 2013, p.8). It is this set of imagined identities that governs the learner's investment in meaningful learning practices, which in turn provides him/her with a wide range of capital. With this departure point in mind, in this autoethnography-based study, I told my own story of language learning and arrived at two findings. One, my identities as a language student, a language teacher, and a language teacher-researcher formed primarily with social factors, especially my imagination of social power gains. And two, my investments in language learning were regulated by these imagined identities and done so in ways that investment was prioritized over the identity related to higher social status and that where my identity was not invested, I took the initiative to invest to realize it.
\end{abstract}

Keywords: post-structuralism, language learning, imagined community, imagined identity, investment

\section{Introduction}

English in the new world order is no longer the predominant language of the Inner Circle countries (McKay, 2010) but has grown into an asset that every global citizen wants a fair share. This is not striking, given as early as 1986 , Kachru came to suggest that the ownership of English means "possessing the fabled Aladdin's lamp, which permits one to open the linguistic gates to international business, technology, science, and travel" (p.1). In that same year, Bourdieu (1986) published his book chapter called The Forms of Capital and used the term capital to underscore the practical values that mastering English affords learners. He posits that capital covers a wide range, including material (income, real estate, wealth), symbolic (language, education, friendship), cultural (knowledge and appreciation of cultural forms and values), and social (connections to networks of power). Regardless of the capital form an individual may wish to gain, learning English provides a means to this end and thus is essentially made integral in his/her academic and professional journeys.

Acquiring the language and hence such forms of capital is, on the other hand, demanding from a post-structuralist point of view. This is an argument by Bonny Norton (2013), one of the most influential scholars who approach second language acquisition (SLA) in a non-traditional way. She argues that language learning is not an activity of an individual in his or her own right but the intertwining of multiple facets: the language, the linguistic community, and the identity he 
or she positions and is positioned by others. Language, according to Norton, is far from having idealized meanings or as a neutral medium of communication but must be understood with reference to its social meaning. Building upon Norton's conception of language, Walsh (1991) adds that it is a vehicle of social practice via which individuals define and negotiate meanings in relation to others. The linguistic community, while deemed "relatively homogeneous and consensual" by structuralists, is envisaged in poststructuralist scholarship as "heterogeneous arenas characterized by conflicting claims to truth and power" (Norton, 2013, p.54). This means that the speaker/learner is not a free self in the community of practice but constrained by myriad discrepancies, e.g. ethnicity, gender, race, and power, which in turn gives $\mathrm{him} / \mathrm{her}$ a set of characteristics referenced as identity. Norton explains identity as "how a person understands his or her relationship to the world, how that relationship is constructed across time and space, and how the person understands possibilities for the future" (p.45). This definition responds, not in a respective manner, to her conceptualization of identity as a trinity of non-unitary essence, a site of struggle, and changing temporally and spatially. Put differently, identity is fluid and contradictory as opposed to being fixed and coherent; supplies room for discourse and thus relations of power to be questioned, negotiated and renegotiated; and changes over historical time and social space. In brief, with the position she takes and the scholarship she draws on (e.g. Bourdieu, 1977; Weedon, 1997; Norton Pierce, 1995), Norton correlates language learning with a social practice in which the individual and the social interact, with stratification of power.

Language learning has also been stressed in identity theories (e.g. Norton \& Toohey, 2001; Kanno \& Norton, 2003; Pavlenko \& Norton, 2007) as inseparable from the notions of imagined community, imagined identity, and investment. I will delve into these notions in the section below, but a glimpse is needed here to explain the departure point of this paper. It is indeed fair to say that learners would not invest their resources in language learning without a relative idea of who they would become and what they would merit in the future. This is depicted as "the power of the imagination" by Norton $(2013, p .8)$, upon which premise she arrives at the formulation of imagined community - a current or future group of people to which the learner feels a sense of belonging, and imagined identity - "a desired sense of self the learners project for themselves" through affiliation with potential communities of practice (Norton, 2001, as cited in $\mathrm{Wu}, 2017, \mathrm{p} .103)$. In this study, the inextricable link among these ideas was illuminated with a focus on the classroom and natural settings as a whole and with the perception that all my study and professional activities were language learning per se.

\section{Literature review}

\section{Investment}

The construct of investment emerged as a result of Norton's (2013) observation that existing scholarship as to the construct of motivation is not congruent with her research data. While learners who experienced language learning failures were often deemed devoid of learning commitment, and there was a dearth of attention paid to unequal relations of power between the learner and the target language speaker, Norton's data lay bare the fact that highly motivated learners were not necessarily successful ones and that power inequity was inevitable in the communication process. For this reason, investment is established by Norton as a sociological construct to complement the psychological construct of motivation (Dornyei, 2001), and hence must be understood within a sociological framework, marked by the relationship between learner identity and learning commitment. In the spirit of Bourdieu's works $(1977,1991)$, investment 
seeks to dismantle the dichotomous views associated with learner identity as good or bad, introvert or extrovert, motivated or unmotivated, etc. In addition to asking "To what extent is the learner motivated to learn the target language?", the teacher or researcher asks "What is the learner's investment in the language practices of the classroom or community?". Further, Darvin and Norton (2015) comment on the motivation versus investment contrast as follows:

While constructs of motivation frequently view the individual as having a unitary and coherent identity with specific character traits, investment regards the learner as a social being with a complex identity that changes across time and space and is reproduced in social interaction. (p.37)

As suggested by this statement, investment is intrinsically bound by the multiple identities leaners take up in different contexts and at different points in time. When learners invest in language learning, they do so with the recognition that they will be rewarded with a broader range of symbolic and material resources, which eventually enhance their cultural capital and social power (Norton \& Toohey, 2011).

\section{Imagined community and imagined identity}

Imagined community and imagined identity are interdependent theoretical constructs that come into existence through "the power of the imagination" on the part of the learner (Norton, 2013, p.8). The term imagined community was originally coined by Anderson (1991) as he redefined nations as imagined communities with the rationale that "the members of even the smallest nation will never know most of their fellowmembers, meet them or even hear of them, yet in the minds of each lives the image of their communion" (p.6). This ideology molded Wenger's (1998) attempt to refute engagement as the mere way to signify the sense of community involvement and to envision imagination as another valid source, and later inspired Norton (2013) to formally develop imagined communities as "groups of people, not immediately tangible and accessible" (p.8). By 'tangible' and 'accessible', Norton refers to diverse communities such as neighborhoods, workplaces, educational sites and religious groups, etc., whose existence is concrete and current, and by 'not immediately' so, she meant the same communities but in near or distant future and which we imagine we would be affiliated with one day. In the realm of SLA, the pertinence of this construct is that learners not only interact with their actual learning spaces but also picture in their mind a set of imagined sites with learning opportunities as powerful as and "no less real than the ones in which they have daily engagement" (Norton, 2013, p.8). This might in turn have an impact on their learning trajectories with an array of accompanying identity positionings, and on the extent to which they invest in their learning experiences. In this regard, Norton (2010) claims that an imagined community assumes an imagined identity, and a learner's investment must be construed in light of this imagined identity construction.

Studies on imagined community, imagined identity, and investment in the world and in Vietnam

While there has been ample research on the constructs of actual identity and investment over the past 20 or so years in most parts of the world (e.g. Duff, 2002; McKay \& Wong, 1996; Skilton-Sylvester, 2002; Haneda, 2005; Potowski, 2007; Cummins, 2006), the relationship between imagined identity and investment has only been explicitly addressed with a modest quantity in more recent scholarship. The contexts in which these studies were conducted were mainly in North America. The foundational study was Norton's (1993) doctoral dissertation which was later published as a book entitled Language Learning, Social Identity, and Immigrant Women in 2000. In this study, Norton analyzed life histories of five immigrant women to Canada in the early 1990s so as to accentuate 
how their investments in English learning were intimately aligned with the varied spheres of their identity and unequal relations of power, either overt or covert, in different contexts. She described how Mai, a bluecollar worker in a fabric factory, in an episode of her professional life, imagined herself as an office worker, so invested in English speaking and writing skills and hoped to gain legitimacy to this imagined community. Nevertheless, while Mai had tremendous motivation to learn, she was insufficiently invested, evidenced by the classroom's focus on past lives of students, and this curbed her from making a connection between her language practices and imagined identity. In a similar vein, Norton examined the narrative of Katarina, a teacher with depth of experience back home and now finding ways to access the professional community in Canada. With her imagination of a professional status, she wanted to take a computer course but was dispirited by her teacher, so she withdrew from her ESL class. In 2011, Chang examined two Taiwanese doctoral students in the United States and argued that the students routinely aligned their investments to their imagined identities. For example, the doctoral candidate named Hou, with an expectation to become a teaching professional, opted to invest immensely in academic writing skills rather than interpersonal skill such as speaking. Later in his study at a Canadian university, Schwieter (2013) designed a semesterlength magazine project for an advanced composition class and assigned participants imagined roles in editorial advisory boards he created as imagined communities. Schwieter's conclusion was that participation in the project fostered students' investment in learning throughout the semester and thus consolidated their writing ability. In her qualitative case study in this same year, Kim found that a Korean graduate student in the United States made investments in academic English, imagining she would be part of a Korean elitist community from which she was able to reinforce her social status and secure financial gains.

Research work on this matter has been even scarcer in the Asian region, however. One such study was $\mathrm{Wu}$ (2017) which looked into anecdotal evidence of three high-achieving English learners in Taiwan and yielded important findings. First, the participants' imagined identities took shape under the influence of specific social and personal aspects and had a marked impact on their choice of learning investments in corresponding phases of their learning adventure. Second, imagined identities, when rationed, limited investment to the school context while gearing it toward both formal and informal settings, if pluralized. With regards to the setting of Vietnam, to the best of my knowledge, no studies have embarked upon the relationship among these notions, so attempts to shed light on this are demanded. Methodology-wise, most studies to date have used a variety of qualitative data collection instruments (e.g. biographical or autobiographical accounts, interviews, informal talks etc.) other than autoethnography research. By approaching a well-established issue from a brandnew methodological lens and in a different geographical region, I sought to answer the following questions:

1. How do my imagined identities form during my language learning process?

2. How do these imagined identities impact my investment in language learning?

\section{Methodology}

\section{Research design}

Identity approaches to language learning broadly and SLA in particular tend to be qualitative rather than quantitative because "static and measurable variables" fail to justify the multiple and changing nature of learner identity (Norton, 2013, p.13). Among a host 
of qualitative methodological foci, narrative accounts are much favored and habitually collected either through field work (Block, 2006; Miller, 2003) or from biographical and autobiographical evidences (Kramsch, 2009). However, these methods often silence the voice of the researcher and turns him or her into an outsider or a mere storyteller of the participants' insights. With a view to locating a method that gives room for my own story to be told in a more vivid manner and in a more appealing writing format so that a connection between myself as the individual and the readers as the social can be produced, I found it plausible to use autoethnography, a variation of ethnography research.

Autoethnography is defined as "research, writing, story, and method that connect the autobiographical to the cultural, social, and political through the study of a culture or phenomenon of which one is a part, integrated with relational and personal experiences" (Ellingson, 2011, p.599). The central idea of this understanding is that the researcher carries out critical analysis of the introspection related to himself or herself in intimate conjunction to the phenomenon or culture under investigation and radiates it to people with cultural homogeneity. It is on this so-called phenomenon or culture that Bochner and Ellis (1996) rely to refute criticism on autoethnography that the research is limited in its conclusions if attached to a personal narrative. Critically, they ask, "If culture circulates through all of us, how can autoethnography be free of connection to a world beyond itself?" (p.24). Like culture, identity and the related matters of imagined identity, investment, and language learning are inherent in each of us, so by using autoethnography to study this relationship, I attempted to make my personal feelings and experiences resonate with individuals within the same language learning culture. A number of advantages can also be documented here to support my choice of autoethnography, including its researcher- and reader-friendliness, its ability to evoke self-reflection and self-examination on the part of the readers and to transform the self and the others in the process of writing and reading the autoethnographical script (Chang, 2008). With respect to the writing style of autoethnography research, Anderson (2006) distinguishes evocative autoethnography from analytic autoethnography. While evocative autoethnography is a form of storytelling that has much resemblance to a novel, biography or an emotional account and primarily concerns the researcher's introspection on a given topic, analytic autoethnography is directed towards objective analysis of a particular group (Ellis \& Bochner, 2000). According to Méndez (2013), evocative autoethnography is gaining momentum in research practice since it allows readers to enter the researcher's private worlds and conversely the researcher to verbalize his or her own inner feelings and thoughts, so it was purposively employed in this study.

\section{Data collection and analysis}

Data collection and data analysis, according to autoethnography researchers (e.g. Richardson, 2000; Wall, 2016), should be done simultaneously rather than sequentially. Characterized by a participant-free approach, autoethnography owes its data primarily to the researcher's memory (Chang, 2008). Though personal memory functions as the backbone during the data collection process, the reliability and transparency of such data can be insured and improved by more concrete artefacts such as diaries, journals, books, sketches and the like (Maric, 2011). So, I began by scanning an extended version of my Curriculum Vitae (I often condense my CV in three pages maximum but do keep a longer version of it) where all my major learning and work events and achievements are recorded and arranged in a chronological order. This helped me relive my experiences and string them up in my head to initially form the story although it was still quite fragmented at this point. To further evoke my memory, I 
reviewed an assortment of certificates, my scholarship application pack as well as email and Facebook communications pertaining to my work (e.g. translation, tutoring, news reporting) and study (Bachelor's, Master's). With the obtained information, I was able to add details to the storyline I had formed earlier and started writing a first draft of events of the last ten or so years. While the idea of using artefacts to back abstract memory is central to the data collection process, autoethnographers (e.g. Duncan, 2004; Taber, 2010) also suggest that the experience of family, friends and colleagues can also help enrich and support personal experiences. So, to gain more accurate insights into my family background in the past and my early learning stage, I had talks with my mother. It was after these talks that I wrote a second draft of my autoethnography, one that was full-fledged now and mirrored the most remarkable milestones of my language learning phases. Once the draft was finished, I read it multiple times, trying to maintain a chronological flow of the narration while simultaneously pinpointing the identities that emerged and the investment activities that were performed en route. The final version was thematically analyzed and is presented in the Findings section below.

\section{Ethical considerations and significance of the study}

The caveat about autoethnography research is that attention is pulled towards the self and away from the other, leading to improper and/or inadequate consideration of ethics (Maric, 2011). Though a number of individuals and institutions were mentioned in the autoethnography because of the interactional nature between the individual and the social as far as identity is concerned, I tried to avoid explicit statements about the identities of the individuals and use pseudonyms to safeguard the anonymity of the institutions (Chang, 2008). What seems to be more problematic, however, lies in my present vulnerability, i.e. my story and emotions are exposed to judgements, and my future vulnerability, i.e. the story, in written form, might be subject to changing personal and social perspectives and attitudes as life continues (Tolich, 2010; Wall, 2016). Thus, I tried to be as faithful to my lived experiences as I could, but at the same time not to push my emotions and arguments to the extreme point.

The significance of this study is twofold. First, identity has been under-researched in the context of Vietnam, and the interrelationship among imagined community, imagined identity, and investment has been even more so. By tapping into this matter, the present study aimed to make it better known in the language learning culture that imagination has a pivotal role to play in learners' learning practices and the range of capital from which they can benefit. Second, this study was an attempt to investigate an old issue from a new methodological viewpoint - autoethnography, and to disseminate this approach among qualitative researchers and academic readership as a whole.

\section{Findings}

Starting out with an imagined identity of a language university student

I was born into a family in which educational security was not taken for granted: my parents quit school at a very young age; my mom effortfully maintained a morning outdoors food stall; and my dad worked as a motorbike taxi driver for every single penny. As time passed by, I nurtured and grew the thought that I would not do manual work like them. When high school neared, with an exceptional interest in the English language, I asked my mom to hire me an English tutor who coached me for one month in preparation for my entrance exam to High School $\mathrm{N}$ for gifted pupils in my hometown - Hai Phong. I failed the exam, but not letting myself disheartened by this failure, I kept on learning English during my high school years and developing the long-standing interest into a genuine passion, alongside with my 
newly-established enthusiasm for Chemistry. At the turn of my $11^{\text {th }}$ and $12^{\text {th }}$ grades, I was selected to compete in the city-level contests for excellent students for both the subjects, and I could choose one only. At this very moment did I seriously reflect upon what I would want to learn at college and who I would become later in my life. So, I went for English. In 2007, I succeeded in the university entrance exams to both a local university called $\mathrm{G}$ for civil engineering training and University $\mathrm{H}$ in Hanoi for the English language. I was in a dilemma now. Though my parents persuaded me to stay close to home with their reasoning about the comfort and care I could have been accommodated, I was determined to embark on the adventure of the new land to pursue a language learning major.

\section{Developing an imagined identity of a language teacher}

Matriculating at University $\mathrm{H}$, I formally became an English-major student. It was here that I was initially exposed to language practice with anglophones and that my previous on-going imagination of the merits of knowing English began to turn real - I read about foreign cultures; I socialized with foreign pals; and I had part-time jobs as an English tutor and a translator. As my junior year approached, I sat down and asked myself which professional career I would be pursuing when I left college, the one that would bring me a wide range of social networks and relationships. After some significant selfsearching, I settled upon being an English news presenter and an English teacher. So, I carried on with occasional translation and interpretation deals and one-on-one tutoring, in addition to participation in multiple English clubs, all in quest of a stronger command of English. The summer prior to my senior year, I spent it at the English division of a radio center called I, immersing more deeply in the actual work of a news anchor. When the summer ended, I worked part time for a local TV channel for a few months before having a semester-length break for my graduation thesis in 2012. In May that year, I graduated, and my work at the TV channel resumed on a full-time basis. The turning point came soon afterwards when one day in August, I was offered the position Head of English News Program. I turned down the promotion to my own surprise and insisted that I was going to become an English teacher. That saddened relations of mine, for they thought I let go a title, a stable income, and a chance to reach out to a circle of individuals with social ranks from all walks of life. I rationalized with them about the same set of benefits I could reap and on top of that a solid educational foundation I could lay for my future family being a teacher. In fact, I had earlier suspended my work at the TV channel, so I was able to concentrate my full energy on the thesis, thinking to myself that a quality graduation paper would be a facilitative condition for my pursuit of teaching profession.

\section{Moving further with an imagined identity of a language teacher-researcher}

That fall, I formally joined the language teaching faculty at University $\mathrm{H}$ where I had undertaken my graduate study. For at least three years ever since, I had been teaching course after course, witnessing my colleagues delegated the additional task of Bachelor's thesis supervision as Master's degree holders. It crossed my mind from time to time the idea that without greater engagement in research and supervision duties, my doorway to a larger social network would be shut. This instilled in me the will to earn my Master's qualification. To this end, I studied hard for a desirable IELTS certificate, took part in language projects, and then applied for a scholarship. In early 2016, my postgraduate study in TESOL (Teaching English to Speakers of Other Languages) commenced at University A in New Zealand. It was about this time that I started to envision about my further study following this Master's program. Learning that an achiever of 8.0 GPA overall would be granted a guaranteed 
doctoral scholarship at a New Zealand university, I strived for the target. In mid 2017, I returned to University $\mathrm{H}$ and felt even more concretely that possessing the academic knowledge and qualification of a PhD holder would bring me steps closer to an expansion of social relationships. So, I planned to study further. To broaden my academic prospects, I have recently explored opportunities in other countries like Australia and found that the institutions set it amendatory for applicants to hold a Master's by thesis and disqualify those with a Master's by coursework who are deemed less strong in research skills. Only by strengthening my research work, I am aware, am I legitimized as a member of this academic community, where I have no doubt my acquisition of relationships with highprofile language researchers will be fostered.

\section{Discussion}

Research question 1: How do myimagined identities form during my language learning process?

The first question this study sought to answer was how my imagined identities formed during my language learning process. The findings showed that my three imagined identities - a language student, a language teacher, and a language teacher-researcher, were constructed primarily in association with social factors, and at a few points, with individual values. For example, my imagined identity as a language learner was driven by my family' loose economic and educational background. As "I nurtured and grew the thought that I would not do manual work like [my parents]", I started to think about the advantage I could gain if pursuing education. The social impact was even stronger when I decided upon language learning instead of civil engineering training at university, envisioning, albeit with vagueness, the power of knowing a foreign language. This is echoed in Norton's (2013) data that one of her research participants Katarina believed that a good education and knowledge of English would guarantee a wide range of non-manual occupational options in life. The construction of this identity was, on the other hand, not without the consideration of my personal interest. It is important to note here that my imagined identity as a language learner was once jeopardized by my newly found interest in Chemistry as Norton (2013) states that identity changes across time and space. Still, it was not only my greater interest in English that kept me focused on the goal of attaining this symbolic asset (Bourdieu, 1986) but also other individual elements such as background, experience, and competence, which are theorized by Kharchenko (2014) as having a remarkable impact on the formation of imagined communities and imagined identities.

When I became a university student, my imagined professional identity as a language teacher took shape as a result of my imagination of the social status associated with this career. Yet, before feeling at ease with this identity, I faced the reality that identity is fluid and plural (Norton, 2013) when I had to choose whether to become a language teacher or a news anchor. As far as personal interest is concerned, I could have invested in the identity of a news anchor for its not less varied social relationships, but it was the social consensus that teaching was among top five prestigious occupations worldwide at that point (The Harris Poll, 2007) that directed me at the other. This practice can be similarly found in Norton (2013). She found that Mai, a blue-collar worker in a Canadian fabric factory, imagined herself belonging to the community of office workers because it was where she would have greater social status. Or in the case with Katarina, being detached from the professional community in Canada, she imagined the status of a teacher she had had back home in Poland. In a similar spirit, Kim (2013) demonstrated the Korean elitist community of which a Korean graduate imagined herself as a member and was able to 
consolidate her social power gains. My data and these findings are synonymous in that an imagined identity should be understood with reference to the learner's evaluation of the share of social capital he/she can gain being part of that imagined community.

My imagined professional identity was cultivated into a language teacher-researcher some time after my identity as a language teacher was fulfilled. Again, as unearthed by the data, this imagined identity was far from disengaged with my expectations for wider networks of social relations. After three years during which teaching was my only task while I wished to supervise Bachelor's theses as well, I started to negotiate access to this type of work by imagining myself as a Master's degree holder and later as a doctoral degree holder in order to expand my social relationships with academia even further. It is noteworthy here that while my two other imagined identities formed without myself interacting with inequitable power relations, institutional experiences placed me in such unavoidable encounters. As a case in point, without a Master's certificate, I was not in position to do supervisory chore which was held by those of my colleagues with ownership of greater symbolic capital (e.g. assumed higher command of English and Master's or PhD qualification) (Bourdieu, 1986). So, I had to depend on these 'old-timers' to grant me the permission to join this community with which they themselves were not entitled because of the established system (Lave \& Wenger, 1991, p.100). This is indexical of the fact that power operates at both the micro level of daily social encounters between individuals with differential possession of symbolic and material repertoires and at the macro systems of law, education, and social welfare, etc. (Foucault, 1980). This can be further illuminated by the second circumstance in which I considered pursuing $\mathrm{PhD}$ in some Australian institutions but was automatically disqualified by the system due to my lack of symbolic resource (i.e. a Master's by thesis qualification).

In summary, three imagined identities emerged during my language learning journey, and the construction of these identities must be understood with reference to my aspirations to widen my social networks and at times unbalanced power relations.

Research question 2: How do my imagined identities impact my investment in language learning?

The three imagined identities elicited in the previous section are those of a language learner, a language teacher, and a language teacher-researcher. The data showed that these identities formed in connection to my imagination of social capital I would benefit when they turned real, and to unequal relations of power. It is also clear from the data that these identities governed my multiple investment activities in different language learning events. For example, despite my family's poor economic and educational background, I did not deprive myself of the identity of an English learner by asking for a short-term tutor and conquering the exam to High School $\mathrm{N}$. Later as a university student, I invested in the imagined identity of a language teacher by reading English materials, befriending with foreigners, partaking in English clubs, doing interpretation and translation work, and tutoring. I did all of these with a view to fulfilling my aspiration to become a language teacher, the profession that put me in contact with higher social relationships. In Norton and Toohey's (2011) words, in so doing, learners are awarded with a wider range of symbolic and material resources, which ultimately enhance their cultural capital and social power. As a further illustration of this, projecting that I would continue with PhD study, I focused my utmost energies on achieving a GPA of 8.0 to secure a guaranteed doctoral scholarship during my Master's program. In his or her study, Wu (2017) also found such investments with two participants Brie and Alicia, whose respective imagined identities as an English teacher and a proficient English user led to their efforts to strengthen their language skills. 
In an attempt to contrast the constructs of motivation and investment, Darvin and Norton (2015) claim that "investment regards the learner as a social being with a complex identity that changes across time and space and is reproduced in social interaction" (p.37). This understanding of investment can be exemplified by the two circumstances in which when my imagined identities were plural at the same time, I struggled to choose appropriate investment directions. One was the struggle between an imagined identity of a civil engineering student and that of a language student, and the other was between a news anchor and a language teacher. It was my adherence to social power gains that navigated my investments in the identities of a language student and a language teacher, evidenced by my choice of the English contest, pausing work at the TV channel for my graduation thesis and so on. What is more, my investments at times must be understood with reference to dynamic negotiation of power (Norton Peirce, 1995). For example, even though I was self-motivated to supervise Bachelor's theses, my lack of symbolic resources curbed me from being invested, so I took the initiative to invest in my imagined identity as a Master's degree holder. Likewise, the fact that I was not invested when it comes to $\mathrm{PhD}$ entry requirements of some Australian institutions led me to make investments in my research work. Indeed, it is not just about learners' motivation to learn the language, but equally about the extent to which they are invested to do so (Norton, 2013). In brief, my imagined identities influenced my investment in two ways: where there were multiple identities at the same time, the one that would lead me to gain more social power was prioritized, and in cases that I was not invested, I took the initiative to invest towards positions with social status.

\section{Conclusion}

Drawing on Norton's (2013) poststructuralist notions of identity and language learning, this study further brought into prominence related concepts of imagined community, imagined identity, and invesment. In so doing, I employed autoethnography as the methodological approach, in which I told my own story of language learning and found three imagined identities as a language student, a language teacher, and a language teacherresearcher. These identities formed mainly with social factors and guided my investment in ways that social power was targeted throughout and that where my present identity was not invested, I invested in it and tried to make it become real. Based on these findings, the study stressed the importance of imagination of identities in association with different capital forms because they would steer learner's investment activities to create meaningful language practices, and thus would lead them to desirable academic and professional experiences.

I acknowledge that language learning is an idiosyncratic experience embodied by diverging patterns, so the limitation of this paper is, first, in its generalizability. Second, though the format of an autoethnography can be stimulating to readers, the accuracy and adequacy of information may be traded off to a certain extent due to the overreliance on memory, not to mention formal ethical procedures being hard to attain. Replication research can be conducted in order to compare findings and shed further light on the interdependence of the notions being investigated. Also, further studies could limit the scope to the classroom context and look into how these notions manifest with teacher-student interactions.

\section{References}

Anderson, B. (1991). Imagined communities: Reflections on the origin and spread of nationalism (rev. ed.). New York: Verso.

Anderson, L. (2006). Analytic autoethnography. Journal of Contemporary Ethnography, 35, 373-395.

Block, D. (2006). Multilingual identities in a global city: London stories. London: Palgrave.

Bochner, A. P., \& Ellis, C. (1996). Talking over autoethnography. In C. Ellis \& A. P. Bochner (Eds.), Composing Ethnography: Alternative Forms of Qualitative Writing (pp. 13-45). Walnut Creek, CA: Alta Mira Press. 
Bourdieu, P. (1977). The economics of linguistic exchanges. Social Science Information, 16(6), 645-668.

Bourdieu, P. (1986). The forms of capital. In J. F. Richardson (Ed.), Handbook of Theory and Research for the Sociology of Education (pp. 24158). New York, NY: Greenwood Press.

Bourdieu, P. (1991). Language and symbolic power (J. B. Thompson, ed.; G. Raymond \& M. Adamson, trans.). Cambridge: Polity Press.

Chang, H. (2008). Autoethnography as method. Walnut Creek: Left Coast Press.

Chang, Y. (2011). Picking one's battles: NNES doctoral students' imagined communities and selections of investment. Journal of Language, Identity, and Education, 10, 213-230.

Cummins, J. (2006). Identity texts: The imaginative construction of self through multi-literacies pedagogy. In O. Garcia, T. Skutnabb-Kangas, \& M. Torres-Guzman (Eds.), Imagining Multilingual Schools: Language in Education and Globalization (pp. 51-68). Clevedon, UK: Multilingual Matters.

Darvin, R., \& Norton, B. (2015). Identity and a model of investment in applied linguistics. Annual Review of Applied Linguistics, 35, 36-56.

Dornyei, Z. (2001). Motivational strategies in the language classroom. Cambridge: Cambridge University Press.

Duff, P. (2002). The discursive co-construction of knowledge, identity, and difference. An ethnography of communication in the high school mainstream. Applied Linguistics, 23, 289-322.

Duncan, M. (2004). Autoethnography: Critical appreciation of an emerging art. International Journal of Qualitative Methods, 3(4), 1-14.

Ellingson, L. L. (2011). Analysis and representation across the spectrum. In N. K. Denzin \& Y. S. Lincoln (Eds.), The SAGE Handbook of Qualitative Research (4 $4^{\text {th }}$ ed.) (pp. 595-610). Thousand Oaks, CA: SAGE.

Ellis, C., \& Bochner, A. P. (2000). Autoethnography, personal narrative, reflexivity: Researcher as subject. In N. K. Denzin \& Y. S. Lincoln (Eds.), Handbook of Qualitative Research (pp. 733-768). London: SAGE.

Foster, K., McAllister, M., \& O'Brien, L. (2006). Extending the boundaries: Autoethnography as an emergent method in mental health nursing research. International Journal of Mental Health, 15, 44-53.

Foucault, M. (1980). Power/Knowledge: Selected interviews and other writings, 1972-1977 (C. Gordon, trans). New York: Pantheon Books.

Haneda, M. (2005). Investing in foreign-language writing: A study of two multicultural learners. Journal of Language, Identity, and Education, 4(4), 269-290.

Kachru, B. B. (1986). The Alchemy of English. Oxford: Pergamon Press.
Kanno, Y., \& Norton, B. (2003). Imagined communities and educational possibilities: Introduction. Journal of Language, Identity, and Education, 2(4), 241-249.

Kharchenko, N. (2014). Imagined communities and teaching English as a second language. Journal of Foreign Languages, Cultures and Civilizations, 2(1), 21-39.

Kim, J. (2013). Korean ESL graduate students' investments, social identities, and imagined communities (Unpublished M.E. thesis). University of Washington.

Kramsch, C. (2009). The multilingual subject. Oxford: Oxford University Press.

Lave, J., \& Wenger, E. (1991). Situated learning: Legitimate peripheral participation. Cambridge: Cambridge University Press.

Maric, P. (2011). Researching the self, the other and their relationship in physiotherapy (Unpublished master's dissertation). Auckland University of Technology, Auckland, New Zealand.

McKay, S. \& Wong, S. C. (1996). Multiple discourses, multiple identities: Investment and agency inn second language learning among Chinese adolescent immigrant students. Harvard Educational Review, 66(3), 577-608.

McKay, S. L. (2010). English as an international language. In N. H. Hornberger \& S. L. McKay (Eds.), Sociolinguistics and Language Education (pp. 89-115). Bristol, UK: Multilingual Matters.

Méndez, M. (2013). Autoethnography as a research method: Advantages, limitations and criticisms. Colombian Applied Linguistics Journal (Print version), 15(2).

Miller, J. (2003). Audible difference: ESL and social identity in schools. Clevedon: Multilingual Matters.

Norton Pierce, B. (1995). Social identity, investment, and language learning. TESOL Quarterly, 29(1), 9-31.

Norton, B. (2013). Identity and language learning: Extending the conversation ( $2^{\text {nd }}$ ed.). Multilingual Matters.

Norton, B., \& Toohey, K. (2001). Changing perspectives on good language learners. TESOL Quarterly, 35(2), 307-322.

Norton, B., \& Toohey, K. (2011). Identity, language learning, and social change. Language Teaching, 44, 412-446.

Pavlenko, A., \& Norton, B. (2007). Imagined communities, identity, and English language teaching. In J. Cummins \& C. Davison (Eds.), International Handbook of English Language Teaching (pp. 669-680). New York: Springer.

Potowski, K. (2007). Language and identity in a dual immersion school. Clevedon, UK: Multilingual Matters.

Richardson, L. (2000). New writing practices in qualitative research. Sociology of Sport Journal, 17, 5-20.

Schwieter, J. W. (2013). The foreign language imagined 
learning community: Developing identity and increasing foreign language investment. In D. J. Rivers \& S. A. Houghton (Eds.), Social Identity and Multiple Selves in Foreign Language Education (pp. 139-155). London: Bloomsbury.

Skilton-Sylvester, E. (2002). Should I stay or should I go? Investigating Cambodian women's participation and investment in adult ESL program. Adult Education Quarterly, 53(1), 9-26.

Taber, N. (2010). Institutional ethnography, autoethnography, and narrative: An argument for incorporating multiple methodologies. Qualitative Research, 10(1), 5-25.

The Harris Poll \#77. (Aug. 1, 2007). Firefighters, scientists and teachers top list as "Most prestigious occupations," according to latest Harris Poll. Harris Interactive.

Tolich, M. (2010). A critique of current practice: Ten foundational guidelines for autoethnographers. Qualitative Health Research, 1-12. DOI:10.1177/1049732310376076
Tullis, J. (2013). Self and others: Ethics in autoethnographic research. In S. Holman Jones, T. E. Adams, \& C. Ellis (Eds.), Handbook of autoethnography (pp. 244-261). Walnut Creek, CA: Left Coast Press.

Wall, S. S. (2016). Toward a moderate autoethnography. International Journal of Qualitative Methods, 1-9. DOI: $10.1177 / 1609406916674966$

Walsh, C. A. (1991). Pedagogy and the struggle for voice: Issues of language, power, and schooling for Puerto Ricans. Toronto: OISE Press.

Weedon, C. (1997). Feminist practice and poststructuralist theory ( $2^{\text {nd }}$ ed.). London: Blackwell.

Wenger, E. (1998). Communities of practice: Learning, meaning, and identity. New York: Cambridge University Press.

West, C. (1992). A matter of life and death. October, 61(20-23).

Wu, H. (2017). Imagined identities and investment in L2 learning. Taiwan Journal of TESOL, 14(2), 101-133.

\title{
CộNG ĐỒNG TƯởNG TƯợNG, BẢN NGÃ TƯởNG TƯợNG VÀ ĐẦU TỦ VÀO VIỆC HỌC NGÔN NGỮ: TƯ GÓC NHÌN CỦA NGHIẾN CÚ'U TỬ NGÃ
}

\author{
Nguyễn Xuân Nghĩa \\ Viện Ngoại ngũu, Truờng Đại học Bách khoa Hà Nội \\ Số 1 Đại Cồ Việt, Hà Nội, Việt Nam
}

Tóm tắt: Dưới lăng kính của Hậu cấu trúc luận, việc học ngôn ngữ không còn là hoạt động của một cá nhân riêng lẻ mà là một tập quán xã hội mà ở đó bản ngã luôn ở trạng thái thay đổi và đa chiều của người học tương tác với các mối quan hệ quyền lực không bình đẳng. Tuy nhiên, không phải lúc nào quá trình học ngôn ngữ cũng diễn ra với bản ngã và cộng đồng ở thực tại mà thường là những bản ngã và cộng đồng được hình thành thông qua "trí trưởng tượng" của người học. Bản ngã tưởng tượng này sau đó ảnh hưởng tới đầu tư của người học vào việc học ngôn ngữ và giúp họ đạt được những lợi ích về vật chất hoặc các mối quan hệ xã hội. Đây chính là xuất phát điểm của nghiên cứu này, từ đó tôi áp dụng phương pháp nghiên cứu tự ngã kể lại câu chuyện học ngôn ngữ của chính mình và đi đến hai kết quả như sau. Một là, bản ngã người học ngôn ngữ, giáo viên ngôn ngữ và giáo viên-nhà nghiên cứu ngôn ngữ của tôi được hình thành song song cùng các yếu tố xã hội, đặc biệt là việc mở rộng các mối quan hệ xã hội. Hai là, các bản ngã tưởng tượng này quy định việc đầu tư vào việc học của tôi thông qua một số cách thức. Cụ thể, bản ngã nào gắn liền với địa vị xã hội cao hơn sẽ được ưu tiên đầu tư, và nếu một bản ngã không nhận được đầu tư trong quá trình tương tác xã hội, tôi sẽ chủ động đầu tư để hiện thực hoá bản ngã đó.

Tù khoá: hậu cấu trúc luận, học ngôn ngữ, cộng đồng tưởng tượng, bản ngã tưởng tượng, đầu tư 